\title{
URBAN CRISIS AND THE ANTIVALUE IN DAVID HARVEY
}

https://doi.org/10.4215/rm2020.e19031

\author{
Márcio Moraes Valença ${ }^{*}$
}

(a) $\mathrm{PhD}$ in Geography. Professor at the Federal University of Rio Grande do Norte (UFRN), Natal (RN), Brazil

ORCID: https://orcid.org/0000-0002-7318-6606. LATTES: http://lattes.cnpq.br/7057449448661416.

\author{
Article history: \\ Received 09 October, 2020 \\ Accepted 12 October, 2020 \\ Publisher 15 December, 2020
}

(*) CORRESPONDING AUTHOR

Address: Av. Bernardo Vieira, 4355, ap.302, CEP:59.015-450, Tirol, Natal (RN), Brasil. Phone: (084)99177-0606

E-mail: marciovalenca10@gmail.com

\begin{abstract}
This text discusses the relation between the urban crisis today and the anti-value in respect to the conceptual framework set by David Harvey. The world today, which is increasingly urban, is dominated by the Empire of anti-value, especially in the form of a growing debt. The anti-value, in the form of capital holder of interest, plays a crucial role in the accumulation of capital, articulating production, circulation and realization of commodities, promoting and facilitating the geographical movement of capital and the transfer of capital between economic circuits and cycles of production. However, debt is the favorite form of anti-value under capitalism today. In addition to being supported and granted by the State in a variety of ways, including through public debt, debt imprisons all economic agents in perpetual servitude. Debt follows the tendency of continuous production of value and surplus value under capitalism, a movement that Harvey calls bad infinity. Anti-value in its form of debt is also called fetishism of capital, which defines the contradictory situation in which money alone seems to have the magic powers to create more money. The consequences of growing debt to the urban crisis go beyond the necessity of solving fiscal problems of the State. The need to produce value and surplus value, in addition to the service of the debt generates urban spaces marked by gentrification and segregation.
\end{abstract}

Keywords: Urban Crisis. Anti-value. Fixed Capital. Built Environment. Debt.

\section{Resumo / Résumé}

\section{CRISE URBANA E O ANTIVALOR EM DAVID HARVEY}

Neste ensaio, discutimos a relação entre a crise urbana contemporânea e o antivalor no pensamento de David Harvey. O mundo contemporâneo, crescentemente urbano, é dominado pelo império do antivalor, em especial na forma crescente de dívida. O antivalor, na forma de capital portador de juros, tem papel crucial na reprodução do capital, articulando produção, circulação e realização das mercadorias, promovendo e facilitando o movimento geográfico do capital além das transferências entre circuitos econômicos e ciclos de produção. A dívida, no entanto, é a forma favorita do antivalor sob o capitalismo contemporâneo. Além de ser lastreada pelo Estado de várias formas, inclusive por meio da dívida pública, a dívida aprisiona todos os agentes econômicos numa servidão perpétua. A dívida acompanha a tendência do capitalismo de produzir valor e mais-valor continuamente, o que Harvey denomina de má infinidade. O antivalor em sua forma de dívida é também denominado fetichismo do capital, termo que designa a contraditória situação em que o dinheiro sozinho parece ter a qualidade mágica de gerar mais dinheiro. As consequências para a crise urbana vão além da própria necessidade de resolver problemas fiscais do Estado. A necessidade crescente de conciliar produção de mais-valia com o serviço da dívida gera espaços diferenciados na cidade, dominados pela gentrificação e pela segregação.

Palavras-chave: Crise urbana. Antivalor. Capital fixo. Espaço construído. Dívida.

\section{CRISE URBAINE ET L'ANTIVALEUR CHEZ DAVID HARVEY}

Ce texte traite de la relation entre la crise urbaine contemporaine et le concept d'antivaleur dans la pensée de David Harvey. Le monde contemporain, en croissance urbaine, est dominé par l'empire de l'antivaleur, particulièrement sous la forme croissante de dette. L'antivaleur, sous la forme de capital à intérêt, joue un rôle essentiel dans la reproduction du capital, en articulant production, circulation et réalisation des marchandises, promouvant et facilitant le mouvement géographique du capital en plus des transferts entre circuits économiques et cycles de production. La dette, cependant, est la forme privilégiée de l'antivaleur sous le capitalisme contemporain. En plus d'être soutenue par l'Etat sous de différentes formes, y compris par le moyen de la dette publique, la dette condamne à tous les agents publics un asservissement éternel. La dette accompagne la tendance du capitalisme à constamment produire valeur et plus-values, ce que Harvey nomme mauvaise-infinité. L'antivaleur sous sa forme de dette est aussi désigné de fétichisme du capital, terme qui fait référence à la contradictoire situation dans laquelle l'argent paraît acquérir la qualité magique de produire plus d'argent. Les conséquences de la crise urbaine vont au-delà de la nécessité de résoudre des problèmes fiscaux de l’État. Le croissant besoin de concilier la production de plus-value avec le service de la dette, produit des espaces différenciés dans la ville, dominés par la gentrification et la ségrégation.

Mots-clés: Crise Urbaine. Antivaleur. Capital Fixe. L'espace Construit. Dette. 


\section{INTRODUCTION}

An analysis of David Harvey's intellectual works is neither obvious nor easy. He is constantly dialoguing back and forth with the works of Karl Marx in search of a better critical reading and to adapt to the present context. Those fully aware of the path that capitalism has been following over the past 150 years will recognize that this takes a herculean effort. Hence, it explains the renowned geographer's importance in the current academic context. Beyond that, Harvey seeks to interpret the city and urban development in the context of financial capitalism. It is within cities that capitalism finds its most fertile ground to develop and why urbanization has been growing at a rate never speculated by Marx when he wrote on the subject in the mid-nineteenth century.

In this essay, we will address the current urban crisis. We will use the book The madness of economic reason (HARVEY, 2018), which is largely theoretical, as our starting point. Harvey does not specifically address the city in this book; however, it is impossible to read it without considering the city. There is very little in this book that has not already been published in his other books (some of which will also be mentioned in this essay). That is the author's modus operandi: in each of his works he adds layers of new understandings onto the same themes that have already been addressed and he updates and perfects his previously elaborated concepts. What sets this new book apart is the clarity and objectivity with which he explains the topics, as complex as they may be. Moreover, what stands out is the strong presence of the ardent activist for social justice, a theme that has turned him into one of the most cited academics in modern day since publishing Social justice and the city (HARVEY, 1973) almost five decades ago.

To begin, it is important to have a notion, even if only rudimentary, of what has come to be known as the urban crisis. A crisis is some state of ephemeral instability. The urban crisis of recent decades - when not referring to conflicts and wars; demographic imbalance, such as an ageing population; the emptying of centres and/or alleged increased immigration; or "natural" contingencies and disasters, such as Hurricanes Katrina and Sandy and the new coronavirus epidemic - almost always either refers to, or is a consequence of, a fiscal crisis that either limits or makes it impossible for local governments to adequately respond to urban problems, such as upholding the public system, maintaining public services and infrastructure, and covering the costs of new investments. Fiscal crises are almost always solved in one of two ways: public indebtedness, even when public-private partnerships are involved to complete urban works; and/or extra contributions from regional and national governments, in which case indebtedness is either fully or partly transferred to other levels of government, who are also facing fiscal problems. This contradiction is interesting to our debate: the fiscal crisis that local governments have been facing throughout the last four or five decades is mainly related to the fiscal inability of nation states to maintain their system of resource cost transfers to local governments. At least, that is the rhetoric that has been widely adopted by neoliberal politicians around the world.

The fiscal crisis - which has increasingly come to incorporate the high cost of public debt as one of its elements - has been used to justify and promote economic neoliberalization measures, such as trade liberalization, privatizations, state reforms, and deregulation of banks, the financial market and the foreign exchange market. In other words, both the size and cost of the State have been used to explain and justify these neoliberal measures. However, in general, throughout this period, the State has not decreased, but rather has broken tax revenue collection records year after year; it has simply changed its role by reducing spending on social policies and increasing spending on business promotion policies (including public debt service). The ability to use the State as an agent and guarantor of credit operations, including for debt, are many. In this context, the accumulation of debt is progressive and continuous. If the urban crisis is related to this process, then it cannot cease to exist. The implosion of public finances in the context of current globalization is directly related to deepening of public debt and its cost in the state budget.

Anyone who has spent a significant amount of time studying geography will know that every place is unique. Thus, it is almost impossible to refer to the urban crisis as a general condition of all cities and societies and affirm that it manifests itself equally in each of them, or even within them. That said, are there not certain conditions that generate the various crises in the various cities around the world? After all, are we not living the globalization that has been so widely disseminated? Let us construct an answer to this question. The keyword to start this discussion is 'anti-value'. 


\section{THE ANTI-VALUE EMPIRE AS BAD INFINITY}

Harvey (2018) explains that, according to Marx, capital must constantly multiply, which thereby guarantees "infinite" accumulation. "Our understanding of the world is held hostage to the insanity of a bourgeois economic reason that not only justifies but promotes accumulation without limit, [...]" (HARVEY, 2018, p.174). This process has a destructive capacity that has seldomly been projected by experts: "the 'bad infinity' of endless compound growth that can only culminate in devaluation and destruction" (p.174). What appears to be economic growth and progress is based on what the author calls "capital fetishism", whereby "money appears to have the magical power of making more money without cease" (p.174). This is even more clear in this current moment in time in which both financial capital and the urban real estate complex dominate.

Money is a representation of value. It also has other uses, such as providing a means of economic exchange, or serving as savings, reserves for future investments, and/or hoarding. However, money in of itself can either serve as or appear to be a commodity. In this case, its use value represents the property to be borrowed. Thus, it is sold in the market for a price, i.e., its exchange value: interest. In general, this exchange should serve to both enable other capitalists to invest and enable the circulation and fulfilment (consumption) of goods, both of which, in turn, almost immediately generate a return to the commodity production process. In this case, money acts to facilitate production and enable the circulation and fulfilment of goods by anticipating purchases that would otherwise have to wait for several production cycles to be carried out. Money that serves this purpose is also called interest-bearing capital. In other words, by returning to the commodity production and circulation processes, the anti-value plays a fundamental role as productive capital. But when money remains stagnant as anti-value it dissociates itself from the commodity production process and begins to circulate autonomously as a financial asset; it no longer produces value or surplus value. It is also known as fictitious capital. The contemporary world of financial globalization is hostage to money and has become the anti-value empire. In summary:

\footnotetext{
"In the same way that land rent rests on the fiction that land is a commodity that can have a price but no value, so also the credit system rests on the fiction that money is a commodity that has price." (HARVEY, 2018, p.39)
}

But how does this mass of anti-value work? It quickly becomes debt. Harvey explains how this works:

"The contradictory element of this is that the creation of indebtedness from within the financial system
becomes a persistent driver of further accumulation. The frantic search for profit is supplemented by the
frantic need to redeem debts. And some of that frantic search has to find ways to augment the valorisation of
capital in production. Value does not return to the practices of valorisation [...] in the same form that it had
when it began upon its journey. It evolves as it goes and expands as it evolves. But its expansion now
encompasses not only the quest for surplus value but the added necessity to redeem the debts that are piling
up within the distributive network that is required for capital circulation to function effectively." (HARVEY,
2018, p.20)

Harvey also explains the coordination that takes place between the state, the financial system and debt:

"Debt imprisons within certain structures of future value production. Debt peonage is capital's favoured means to impose its particular form of slavery. This becomes doubly dangerous when the power of bondholders subverts and seeks to imprison the sovereignty of the state. It is for this reason that the only mode of capital's survival is through the coherence and fusion achieved through the state-finance nexus. With this, the alienation of whole populations from any real influence and power is complete." (HARVEY, 2018, p.204-205)

In short, "Capital does not forgive us our debts, ... but insists we redeem them through future 
value production." (HARVEY, 2018, p.201)

Thus, in times of global financial capital, the reality is that anti-value is equivalent to debt peonage with state endorsement and coordination. Debt imprisons all economic agents/actors under the logic of contemporary capitalism. And, given the imperative need for infinite capital accumulation, everyone is sentenced to life imprisonment!

But why does Harvey state that debt is capital's "favoured means" of anti-value? There are other ways that money maintains anti-value, given that it circulates in fictitious markets, including those far removed from the everyday labourer, such as the markets for art, gambling, carbon credits, cryptocurrencies, futures trading, and corruption schemes. There are also ways of hoarding that completely remove money from circulation, such as hiding money "under the mattress", in a safe and/or in a foreign currency in cash. Debt, however, grows with credit card purchases; in pension funds, which "invest" a considerable portion of payments in public debt; in loans to and between governments; in bank bailouts from other banks and from central banks; in the insurance market; and in car, appliance and other loans. Moreover, another important element to consider in the urban crisis are the varied and considerable "investments" in the built environment, many in the form of real estate speculation, which are almost always carried out in the form of indebtedness (taking out a loan), both among producers and consumers.

Harvey sums up this process:

\begin{abstract}
"When that money circulates as interest-bearing capital it functions as the anti-value that must be and supposedly will be redeemed by future value and surplus value production. But when the money released circulates into asset markets like property, the stock market and the art market then the anti-value is not redeemed even as the ultra-rich get even wealthier from their speculations. A strong incentive then exists to create even more anti-value to redeem that issued earlier. The result is not only secular stagnation in value production but the creation of a Ponzi capitalism which is the dangerous path of endless monetary expansion [...]" (HARVEY, 2018, p.108)
\end{abstract}

Thus, as previously stated, it is important to emphasize and insist that not all anti-value is destined to be transformed into debt. What Harvey (2018) - always referencing Marx - calls interest-bearing capital plays another role. It is anti-value in transformation: it seeks added value in the production process; it permits capital circulation throughout the entire cycle (production, circulation and realization); it allows capital to circulate between the productive circuits (primary - of commodities in general; secondary - real estate; and tertiary - of science and technology, and education and culture); it allows either the flow of capital or its transfer to other commodity production cycles; it allows capital to flow in geographical space; it even facilitates the distribution of resources (added value) among capitalists. The anti-value, in the form of interest-carrying capital, is auxiliary and of paramount importance to the production process. This is the most liquid form of capital.

When anti-value fails to fulfil this purpose, it increasingly manifests itself as debt. Debts have to be amortized (even unpayable ones). Anti-value used to promote production (and, supposedly, value and surplus value) must now share space with debt service, which impacts future production. As previously mentioned, this dynamic is associated with a continuous and infinite need to produce commodities, i.e., value and surplus value. Once anti-value has been fetishized as debt as if it were a commodity in money form, it begins to reproduce continuously and infinitely (another contradiction!). Its new attribute is to magically turn money into more money. Total alienation! This extends far beyond exacerbated and current consumerism. Neither Karl Marx, in his compendiums on capital (especially, Marx, 1990 [1867]), nor Guy Debord (2003 [1967]), more recently in his writings about the "spectacle" of accumulation, could have foreseen such developments that have become so dominant in recent decades, both in the economic world in general, and in our day-to-day lives.

This is all only possible because of what Marx called the blinding money-form, i.e., the material expression of value (which is immaterial). Money, as it is used to represent exchange values, is a process, not a thing (paper money, gold bars). Its use possibilities are endless. The accumulation of capital is, thus, linked to a rampant accumulation of debts, which has enormous potential to generate crises. "The need to redeem anti-value is a compelling force over value production." (HARVEY, 2018, 
p.78). Non-payment of debts leads to crises, and widespread non-payment of debts can lead to "devaluation and destruction".

Thus, even if only en passant, we review some characteristics of the productive system under capitalism to better understand the effects and role of anti-value in the contemporary urban crisis.

\section{PRODUCTION, CIRCULATION AND REALIZATION OF THE COMMODITY}

To understand the relationship between debt and the urban crisis, i.e., to explain how the contemporary urban crisis is the product of debt (or anti-value in the form of debt), some basic characteristics of capitalism, as Harvey (2018) describes them, based on Marx's narratives, should be reviewed, even if only briefly. Bad infinity of accumulation and the fetishism of money - along with its expansion in the form of debt - can be associated with the production of space and the construction of a geography that is both similar to, and at the service of, capital (the latter topic is also dealt with in Valença, 2006 in more detail). Perhaps the best way to approach this discussion and reach any conclusions is to examine how capital operates in real estate markets, including in the form of fictitious capital, and the role that private property, both land and housing, plays in this process. This will be examined later, in sequence. But first, the most elementary Marxist theory of value will be discussed the production of commodities under capitalism.

Harvey discusses the shaping of Marx more carefully in other books of his, specifically A Companion to Marx's Capital, and A Companion to Marx's Capital Volumes 2 and 3, which were originally published in English in 2010 and 2013, respectively (there is a more recent edition, from Verso Books that joins the two books into a single volume). In these books, Harvey compiled material from courses he taught over the previous four decades on Karl Marx's thinking in Capital. However, I prefer to reference the book The Limits to Capital, which was published in English in 1982. In it, Harvey, despite always referencing Marx's thoughts, developes his own agenda more freely, one that does not necessarily follow Marx's writings in Capital.

Marx examined the production (including the distribution problem, and how salaries, profits, rents, and interests are allocated), circulation and distribution (exchange and consumption) of commodities, in each volume of Capital, respectively. It is common knowledge that books 2 and 3 were published posthumously by his friend and follower, Friedrich Engels. Book 2 was revised and supplemented, and book 3 was written by Engels based on notes left by Marx. Thus, even if we consider Marx's complete legacy of works and contributions, his project, as he had planned it, was incomplete. It is also, therefore, not surprising that book 1 of Capital has become perhaps his most read and well-known oeuvre. Although the project was left incomplete, what Marx did concretely leave behind was a critical theory about the production of commodities under capitalism. Marx understood capital in its totality. Although the production, circulation and distribution stages can be examined separately, they constitute a single, complex, and contradictory process. Time is the key element in all Marxian theory, thus capital is equivalent to its moving value, given that it is in constant transformation on the path to infinity. Its goal, or rather its plan, is to continuously expand.

Value is equivalent to the socially necessary labour time in society to produce commodities. However, a good produced under capitalism does not become a commodity without first passing through a process of circulation and distribution. Commodities are goods with a use value for someone else, not for their producer. Commodities are exchanged on the market for their exchange value - or for a representation of this value, i.e., money. This exchange is carried out through money. Under capitalism, things are not traded for things, but rather are traded for money or money is traded for things. There is an ideological aspect to this relationship. When someone thinks of having access to some necessary or desired commodity (use value), they also think about mobilizing resources to access it. Access to use values under capitalism occurs through a given commodity's exchange value, by way of buying and selling. This is strongly and ideologically embedded in our minds.

What is accomplished through labour is the product of capitalism. Money (which is concrete) is the measure of the sociability of labour (which is immaterial). Money alienates people from the production process, through what Marx calls commodity fetishism. Commodities become things, rather 
than processes imbued with complex social relationships, the environment, and the built environment. As a result, it is no longer possible to know the origin of goods or the processes under which they are submitted during production and circulation. Money masks reality by mediating exchanges between capitalists, workers, and consumers. And when money - as previously discussed - in of itself is treated as a commodity, fetishism, in its most extreme form, is established. Money as a commodity - the credit and debt system - is the height of alienation.

Capitalists own the means of production, i.e., they have capital to invest. Labourers do not own the means of production; they merely have the labour force, which they exchange in the market for a salary (paid by capitalists). Those are the two fundamental social classes under capitalism: the capitalist class, or bourgeoisie, and the working class, or proletariat. Capitalists establish the cog that turns capital into both commodities and more capital. That is the process that creates value and surplus value. The means of production (equipment, buildings - dead labour) and inputs are provided and, when used adequately with help of the labour force, the magic of transforming goods into other goods occurs. This magic is what gives rise to, and enables, workers to be exploited by capitalists. Capitalists aim to make profits, but how is this possible? Given that the means of production are privately owned, capitalists are able to retain part of the value generated by workers in the production process, i.e., the surplus value. (MARX, 1990 [1867]).

Surplus value is the part the value (the time needed for workers to produce goods) appropriated by the capitalists. The entire process is uneven and combined. Combined meaning that the impoverishment of labourers is associated with the wealth of capitalists. The accumulation of capital is proportional to the accumulation of misery. The degree to which labourers are exploited - the amount of surplus value appropriated by capitalists - depends on a process that is conceptually known as the class struggle. Labourers can organize and fight for better working conditions, such as shorter work days and higher wages, however, capitalists can respond by laying off the labourers who are most politically active and hiring new labourers from the industrial reserve army (generated from the relative overpopulation or, as it is also known, the relative surplus population), or by investing in new technologies, equipment and labour organization (which generate relative overpopulation by replacing live labour with dead labour). The social division of labour, which divides intellectual from manual labour and deprives workers of the know-how by incorporating this know-how into machines and production lines, is what permits constant increases in productivity.

Capitalists seek profits; profits are the concrete form of surplus value, i.e., the portion of value that is generated during the production process that is appropriated by capitalists. Capitalists seek to expand the reproduction of capital. They depend on it to survive the adversities brought on by the competition in the mid and long terms. Therefore, in addition to making profits, at the end of a production cycle capitalists must invest part of these profits into the next production cycles and, thereby, accumulate capital. This is a result of the capitalist competition process, which urges everyone to continue investing to increase productivity, lower production costs, and either maintain or increase profitability. There are several types of capitalists involved in the production and circulation of goods. The industrial capitalists must share the added value (the profit) obtained in the production process with merchant capitalists, financiers, and rentiers, such as land and property owners, among others. The distribution of surplus value among capitalists is also a result of competition. This is not a simple process, but it is facilitated by anti-value, i.e., money in the form of interest-bearing capital, which allows capital to flow more easily between production sectors and geographically. Money is the most mobile form of capital. As Harvey explains, Marx referred to it as the butterfly because it flies and lands wherever it wants. Thus, it is not difficult to understand why current globalization, the Debt Empire, is directly and strongly related to the various types of credit systems.

Given the ease with which capital can move between economic sectors, profit rates tend to balance out. In other words, if, for example, the shoe industry offers more advantages and profitability than the automobile industry, then automobile producers can choose to start investing part of their profits to produce shoes. Capitalists seek profits, regardless of the use value produced. Both large and small investments alter the supply of goods and their related market prices which, in general, follow the law of supply and demand, accepted even by Marx as the guiding principle (there are obvious distortions brought about by monopolies, oligopolies, cartels, taxation, state controls, etc.). The flow of capital has distributive effects and presents a relevant contradiction: greater profitability is not associated with the 
surplus value created, but rather with the capital that capitalists advance. Capitalists strive for "the maximisation of profit rather than the maximisation of surplus value production." (HARVEY, 2018, p.34). Therefore, capital-intensive industries are more favoured, a situation with the potential to generate crises and which greatly explains the regional inequalities in the world.

Before returning to the urban crisis, we will first continue discussing the Marxian principles of the capitalist system and the foundation of fixed real estate capital, an important topic to better understand the relationship between the urban crisis and anti-value. The urban crisis is aggravated by, but not exclusively related to, the state fiscal crisis or, as pointed out at the beginning of this essay, to demographic conditions, wars, and specific natural disasters. Anti-value is more overreaching than its manifestation in the form of public debt alone.

\section{FIXED CAPITAL, BUILT ENVIRONMENT AND CRISES}

Now that we have briefly reviewed some of the founding characteristics of capitalism that Marx described and Harvey presented in many of his works, it is crucial to understand how fixed capital investments (including real estate) are formed, given that they are so important to how the built environment is developed in cities and that they are capable of both alleviating and exacerbating the urban crisis. This is another contradiction in capitalism, a mode of production doomed to crisis. Capital - a value on the move! - always operates on the edge of instability. Let us examine the following statement:

"Fixed and immoveable capital embedded in the land has to be used in situ if its value is to be redeemed over the course of its lifetime. In this there is a paradox. A form of capital designed to provide the physical infrastructure in place to liberate the spatial mobility of capital in general ends up demanding that capital flow into that space which the fixed capital defines or the value of the latter will be devalued with serious consequences for the interest-bearing capital... that funded it. This is one of the potent ways that the crisis tendencies of capital come to a head." (HARVEY, 2018, p.149-150)

The above statement is self-explanatory, however we want to draw attention to the fact that the movement of capital, which requires investment in fixed capital and its variants fixed immovable capital and independent fixed capital, in of itself create a constraint that prevents or hinders the "butterfly's" freedom. It also requires that immoveable consumer goods (such as houses and parks) be produced, investments that are either destroyed or devalued if they must be displaced or abandoned. If, at first, investments are displaced toward a space yet to be built, subsequently new investments should be directed toward this new space, otherwise previously invested capital will become devalued (or lost, in extreme cases). More specifically, the very spatial expansion of capital constrains its movement, given the need to recover the investment.

Harvey's discussion of fixed capital is not an easy read, but it reflects the uncertainties and gaps left by Marx. That said, there is a recurring conceptual misunderstanding that should be clarified. The terms constant capital and variable capital are not synonymous with fixed capital and circulating capital. In The Limits of Capital, Harvey (2013 [1982]) clearly makes this distinction. The first terms refer to the production of value (and surplus value) and define the role of capital in class relationships; the second terms refer to the movement of capital with respect to its use value in production. For example, a factory and its production equipment and raw materials are constant capital, but the workforce is variable capital. The raw materials and workforce are circulating capital. What defines fixed capital is its use in production: the transfer of its value to the final product is different from what occurs with the value of raw material (circulating capital), which are reconstructed completely in the final product. The same cannot be said of fixed capital, which is only partially incorporated into the final product. Fixed capital remains in production for several capital cycles, until the end of its lifetime (which occurs as a result of deterioration or disuse after being replaced by new equipment or more productive technologies). "Fixed capital is, then, only that part of the total social wealth, the total stock of material assets, that is used to produce surplus value" (HARVEY, 2013 [1982], p.283).

The labour tools, which are fixed capital, must be produced as a commodity in capitalism, 
however, fixed capital should not be confused with certain types of consumer goods. Knives, forks, and houses are consumer goods; they do not directly serve to produce. Thus, the issue is much more complex. There are two types of large-scale and long-term fixed capital: what Harvey calls fixed capital of the independent kind (such as roads, railways, canals, ports, etc., which Marx includes in the general production conditions) and fixed capital that is closed in the production process (such as machinery and industrial buildings). Use of the first is shared, whereas use of the second is unique to each production unit. Immobility is another condition that refers both to certain types of fixed capital and certain types of consumer goods (such as a house or a park). Fixed capital is different from consumer goods, however it is possible for something to be both simultaneously, such as roads and vehicles. The distinction is in its use. Ships are not immoveable (they are large-scale and long-term), whereas villas and parks (consumer goods) are immovable. In general, parks are of collective use; houses are of individualized use. There are many combinations.

Fixed capital investments are transformative in capitalism. Fixed capital is directly related to the use of technology and the organization of labour and production. Technology is the base of the competitive struggle (class struggle and capitalist competition) for relative surplus value. Technology has an impact in both determining the level of exploitation of labour and on the distribution of benefits among the various types of capitalists. However, in general capitalists avoid making investments in fixed capital due to many of their intrinsic characteristics, such as: high cost, long production time, difficulty in determining prices given the nature of their use (carried out over several production cycles and/or shared or collective use). This is why it is common for large infrastructure investments, including large industrial projects (such as steel mills and refineries), to be made by the State (or by capitalists with subsidies, guarantees, financing and other tax benefits). Usually, when capital migrates to the real estate sector to the point of causing a boom it is a sign that the economy is in crisis. Notwithstanding, even if this migration of capital is, in essence, an investment with good prospects for profit, between conception, execution and sale, a real estate development takes several years to materialize. Thus, these types of enterprises require large amounts of capital and are pro-cyclical, which means that throughout the long production process capitalists are prone to a demand crisis of their own making. The production of the built environment is an impactful component in a crisis: first, solve; then contribute to aggravating the crisis.

In chapter 2 of his book The urban experience, Harvey (1989) explains that capitalists tend to invest more in the primary production circuit, which is the circuit that produces most commodities. This is yet another contradiction in a system that can lead to over-accumulation crises, which, in general, includes the production of goods with no buyers, decreasing profit margins, unused capital, and unused surplus labour. A response, which is generally temporary, is to transfer capital to the secondary circuit. This circuit is what produces fixed capital and what Harvey calls the consumption fund (commodities that serve as a means to reproduce workers, such as houses, sidewalks, parks, washing machines, etc.), with particular attention to real estate. Moreover, in this circuit both the built environment for production and the built environment for consumption (which often get mixed up) are produced. There is also a tertiary circuit of production that corresponds to investments that are generally long-term in the following areas: science and technology, repression (such as the police and the armed forces), research, education and health, co-optation and integration of the labour force. In a crisis, capital can migrate in different ways - depending on the nature and severity of the crisis - from the primary to the secondary and tertiary circuits (see the discussion in Valença, 2008). However, this does not occur with ease. Harvey warns that:

\footnotetext{
"A general condition for the flow of capital into the secondary circuit is, therefore, the existence of a functioning capital market and, perhaps, a state willing to finance and guarantee long-term, large-scale projects with respect to the creation of the built environment." [...] "This applies as much to the consumption fund (hence the importance of consumer credit, housing mortgages, municipal debt) as it does to fixed capital". (HARVEY, 1989, p.65).
}

A significant element in the production of space is to feed the debt economy. The State is not the only entity who finances part of the production of the space (specifically autonomous, independent fixed capital) through public debt; private entrepreneurs also finance their ventures through banks and/or the 
financial market. Consumers, in turn, must also take out loans to purchase real estate in the market.

"In housing markets, for example, financiers fund developers to produce housing while the same financiers lend to consumers to realise housing values in the market. The circulation of interest-bearing capital bridges the contradictory unity of valorisation and realisation to harmonise both." (HARVEY, 2018, p.43)

However, as already stated, given the time for this whole process to take place, entrepreneurs can become surprised by an overaccumulation crisis in the real estate market. Thus, the fiscal crisis discussion masks a crisis that is much more severe: a State fiscal crisis that becomes a widespread market crisis.

The consequences of the urban crisis, which either occurs or is accentuated by production of the built environment, have an even bigger impact: they stretch beyond the fiscal problems of the State and its inability to provide what is needed; they stretch beyond the financing and debts problems of companies and individuals; in short, they extend beyond the mere accumulation of debt. The urban crisis impacts real estate prices in a given location and the subsequent allocation of more infrastructure, thereby causing gentrification and segregation. This type of crisis leaves an, often permanent, mark on the land.

In summary:

"Fixed capital investment, particularly of an independent kind in the built environment, can provide temporary relief from problems of overaccumulation and relieve stress during phases of crisis when surpluses of capital and of labour exist side by side without otherwise profitable sources of employment. On the other hand, future production and consumption are increasingly imprisoned within fixed ways of doing things and increasingly committed to specific lines of production and particular spatial configurations way into the future. The future is mortgaged to the past. Capital loses its flexibility. (HARVEY, 2018, p.150)

\section{CONCLUSION}

We are coming toward the end of this essay and, thereby, we come back to the urban crisis problem and how it is related to anti-value. Capitalism has many contradictions. The anti-value empire exacerbates and accelerates the tendency toward crises in the system. The need for continuous and infinite accumulation to produce value and surplus value has added the need to ensure debt service, which imposes debt servitude. Value and surplus value need to be produced with greater intensity, which implies constant pressure on economic growth. Perpetual growth must maintain its compound growth dynamic. In other words, the growth of a given year will reference the preceding year's economy, which is even greater than the year before that, and so forth. It is a geometric progression. This growth presents a contradiction in capitalism and is headed toward ecological catastrophe. It is hard to believe that the world economy can grow at a rate of two percentage points or more every year. How can investment opportunities be found? What are the effects of this increasing production on the ecological sustainability of the planet?

Harvey (2013 [1982]) insists that a crisis is a state of either super or overaccumulation wherein there is capital available to be invested yet, at the same time, unemployment. For some reason, these two conditions, which should balance one another out, are not met (see also Valença, 2017). To get out of crisis, even if only temporarily, we have previously seen investments or the conversion of capital into large-scale and long-term fixed capital (machinery, ships, etc.), particularly when it comes to the production of space (autonomous, independent fixed capital, such as roads, bridges, ports, railways and dams; and non-autonomous fixed capital, such as industrial projects and buildings, and warehouses; as well as immovable consumer goods, such as housing, sidewalks, public squares and parks). As previously mentioned, the need to make these transformations work induces the need for new investments; generally, throughout a crisis a new baseline is established to measure the next capital cycle. Crises - Marx insists - provide the possibility for renewal in capitalism. Hence, it is common for capital to build, destroy and rebuild the built environment (as it wishes, to meet its needs) (VALENÇA, 
2006). The preferred space to reproduce capital is the urban space, which is why crises always hit cities. The urban crisis is intrinsically linked to the debt empire.

Some investments are not profitable, which is why the State carries them out with outright grants and/or companies who carry them out become devalued and may even go bankrupt. "Crises typically leave in their wake a mass of devalued assets that can be picked up at fire-sale prices by those who have the cash [...] to pay for them." (HARVEY, 2018, p.86). In general, this is the role of anti-value. There is a relationship between debt and the prospect of survival in contemporary capitalism. Although debt compromises future accumulation, it is also its redemption. There is no greater contradiction. So long as there is a need to accumulate infinitely, debt bondage will continue to perpetuate.

Capitalists have often had to find solutions outside of capitalism to survive crises, such as colonialism, imperialism, and many conflicts and wars. Harvey (2003), in The new imperialism, refers to these types of processes, particularly the geographical expansion of capitalism, as accumulation by dispossession. In the contemporary world of globalization and financialization, both the economy and society have become more complex. Their modi operandi are difficult to explain without adding layers of multiple understandings. Nowadays, there seems to be a bit of everything, however the preferred way for capital to survive crises has been to spread the credit and debt system.

Until now we have avoided using the hated term financialization. It has been used excessively to define all the evils of the contemporary world. Whatever it means, it would not be necessary to explain the subject of our discussion in detail if the term financialization were used. It appears to be self-explanatory and widely understood. That is not the case. Financialization, which is an instrument of the debt empire, merely operationalizes both the production of value and surplus value and, increasingly, the accumulation of debts. Financialization manages to keep us all stuck in the system, with our hands tied. Even if an individual does not have any "debts", the world around them operates under the credit economy logic, with rising and falling interest rates, and variations in stock exchange indices, the dollar, the exchange rate, and credit, etc. These things have become determinants in our everyday lives, in defining public policies, in social groups and regions that either win and lose, and in the prices practiced in the market. This instrument of economic domination advances daily in the different economic sectors and fields of everyday life.

A way to exit crises has been to build infrastructure, such as roads, and durable consumer goods, such as housing. Building houses then filling them with things has been a recurring act in the history of capitalism. This was the successful formula adopted in the post-Second War Fordist era, which involved American suburbanization and the reconstruction of Europe and Japan. Today it is the flagship of Chinese development. In the 1990s, it served to reunite Germany after the fall of the Berlin Wall, turning the great city into the largest construction site on the planet at the time. In the following decade, it served to build Dubai, on a scale and at a speed never before seen. This formula is well known and advertised as a solution to crises (whether they be partial or full on global crises) in cities and countries around. It is common to use job creation and business opportunities to justify these actions, as we have seen recently in Brazil with the PAC (Growth Acceleration Program, 2007) and PMCMV (My House My Life, 2009) programs. Today, financial capital is more integrated with real estate than before. In times of crises and instability, real estate is produced to store value, for the wealthy to acquire (which they call investments). Therefore, "Capital is building cities for people and institutions to invest in, not cities for the common people to live in." (HARVEY, 2018, p.189).

Together, the financial and the real estate markets create a complex. Nevertheless, there needs to be assurance that debts incurred will be paid (or amortised) for that the system to avoid entering a deep recession or depression. To that effect, the State guarantees the proper functioning of banks and financial corporations. Banks cannot go bankrupt so they are bailed out at all costs. What guarantees the steady movement of capital in the world today, which we call globalization, is the freedom to operate and the mobility of financial capital in markets that operate 24 hours a day. Everything else falls behind. This partly explains why crises spread so rapidly: the financial markets of various countries are globally integrated and, as such, they contaminate one another. Thus, globalization is the globalization of debt and the anti-value empire. While crises continue to occur, banks and financial corporations, and depositories and money operators, register record profits.

This discussion could continue ad infinitum, just like the accumulation of capital, the debt empire 
and the prolongation of the urban crisis do: everything Harvey calls "bad infinity". However, we must bring it to a provisional close that will enable us to see the light at the end of the tunnel. And Harvey allows us to see this light in one of his moments of lucid optimism:

"Capital produces a cornucopia of use values from which it is in principle possible for people to create unalienated social relations and ways of being in nature and with each other. The potentiality is there. The world is dotted with heterotopic spaces in which groups strive to construct unalienated ways of living and being in the midst of a sea of alienation." (Harvey, 2018, p. 194)

\section{ACKNOWLEDGMENT}

To CNPq, for the financial support received by the author through a PQ1-B scholarship. Thanks to professors Renata Archanjo and Sara Raquel Fernandes Queiroz de Medeiros for important comments on a previous version. Thanks to Professor Sylvia Abbott for her careful review. Thanks to CAPES for financial support of the English translation.

\section{REFERENCES}

DEBORD, Guy. A sociedade do espetáculo. São Paulo: eBooksBrasil, 2003 [1967]. E-book.

HARVEY, David. The urban experience. Oxford: Basil Blackwell, 1989.

HARVEY, David. Social justice and the city. Oxford: Blackwell, 1993 [1973].

HARVEY, David. The new imperialism. Oxford: Oxford University Press, 2003.

HARVEY, David. Os limites do capital. São Paulo: Boitempo, 2013 [1982].

HARVEY, David. A loucura da razão econômica: Marx e o capital no século XXI. São Paulo: Boitempo, 2018.

MARX, Karl. Capital. A critique of political economy. v. 1. London: Penguin Books, 1990 [1867].

VALENÇA, Márcio Moraes. Cidades ingovernáveis? Ensaio sobre o pensamento harveyano acerca da urbanização do capital. In: SILVA, José Borzacchiello da; LIMA, Luiz Cruz; ELIAS, Denise (org.). Panorama da Geografia Brasileira. São Paulo: Annablume, 2006. p. 185-190.

VALENÇA, Márcio Moraes. Ensaio sobre a dinâmica do imobiliário em Harvey. In: VALENÇA, Márcio Moraes. Cidade (i)legal. Rio de Janeiro: Mauad, 2008. p. 243-250.

VALENÇA, Márcio Moraes. Harveyan utopian thought and social justice. Approaching public space. In: MENDES, Manuela M.; SÁ, Teresa; CABRAL, João (ed.). Architecture and the social sciences. Inter- and multidisciplinary approaches between society and space. Berlin: Springer, 2017. p. 86-96. 